\title{
ДИСКУРСИВНИЙ АНАЛІЗ МУЛЬТИДИСЦИПЛІНАРНИХ ДОСЛІДЖЕНЬ У ПСИХОЛІНГВІСТИЦІ
}

\section{Discourse Analysis of Multidisciplinary Research in Psycholinguistics}

\author{
Tamara Tkach \\ DSc. in Psychology, Professor \\ Pereiaslav-Khmelnytskyi Hryhorii Skovoroda State Pedagogical University (Ukraine) \\ tkachtam@gmail.com \\ https://orcid.org/0000-0001-5290-5395
}

\begin{abstract}
The article examines the transition of modern science to multidisciplinary discourse, which makes it necessary to conceptualize and possibly operationalize methods of psycholinguistics. The conceptualization of new areas in a psycholinguistic context, presupposes a certain mental experience that includes, in addition to the processes of creating new concepts and contextual knowledge, also defining the role of interests, intentions, emotions in human activity.
\end{abstract}

Keywords: multidisciplinary nature of research, psycholinguistic discourse.

\section{Ветуп}

Introduction

Поява нових наукових галузей в останні десятиліття значно розширили поле психолінгвістики. Зараз дещо дивним видається, що ще років 20-30 тому багатьох дефініцій, термінів, i, навіть, назва нових сфер науки просто не існувало. На початковому етапі цього періоду в науковому середовищі відчували певне потрясіння, багато нових основних понять, дефініцій піддавалися ретельному перегляду. У міру поглиблення i розширення знань про нейроні, психологічні, лінгвістичні і біологічні особливості сприйняття та обробки інформації все більший інтерес вчені стали проявляти до механізмів мотивацій і дій на основі прийняття рішень, теорії вибору і моделювання поведінки суб'єктів діяльності. 3 багатьох нововведень найбільший розвиток отримали подвійні поняття та психології, економіки, права та інших сфер науки. Було визнано, що такий зв'язок, безсумнівно, має мультидисциплінарний характер, що сприяє поглибленню відносин між науковою 
думкою, культурою і мовою, стало поштовхом для розуміння природи людського пізнання на більш високому, мультидисциплінарному рівні розвитку науки. В останньому меморандумі Римського клубу ця тенденція була позначена як «ідея формування цілісного світогляду і нового змісту освіти і науки» (Weizsäcker \& Wijkman, 2018). Жодне з наукових досліджень не обходиться без аналізу понять, дефініцій, термінів.

Мета дослідження полягає у вивченні та розширенні психолінгвістичного аналізу мультидисциплінарного формату нових наукових сфер, який заснований на нових досягненнях в нейропсихолінгвістиці економіки і їі модифікаціях.

\section{Методи та методики дослідження} Methods and Techniques of the Research

У процесі теоретичного дослідження було застосовувано багатофакторний аналіз мультидисциплінарного характеру нових тенденцій i закономірностей $\mathrm{y}$ розвитку наукових теорій. Посилення невизначеності та непередбачуваності в іiі інституційному середовищі створило можливість психолінгвістичного осмислення значень і структури нових наукових понять, термінів і дефініцій. Це стало важливим компонентом для встановлення об’єктивної наукової істини, а також комунікацій в ширшому науковому діапазоні.

Застосування методу порівняльного аналізу дозволяє будувати на фактичному матеріалі наукові гіпотези щодо подальшого шляху розвитку стимулює розвиток $\mathrm{i}$ конкретизацію психолингвистических знань, сприяє їх практичного використання.

У процесі психолінгвістичного дискурсу нейроекономіки використовувався, також такий метод наукового дослідження, як екстраполяція. Його результати $\epsilon$ однією 3 важливих складових наукового пояснення психолінгвістичного аналізу складних мультидисциплінарних взаємодій.

\section{Результати \\ Results}

Мультицисциплінарність наукових досліджень передбачає володіння вченими мовою однорідного мовного співтовариства і уникнення помилок у використанні мови. Саме такий підхід сприяє розвитку мовної компетенції, яку N. Chomsky (1965) визначає як частина ментальної реальності, а лінгвістична теорія, що відноситься до неї, вважається менталістичною теорією. Така теорія дозволяє людським мовам пояснити, як з'являються унікальні і автономні системи в психічній сфері людини i 
вивчати їх іманентні структури. Подолання лексичного бар'єру пов'язане 3 оволодінням певним термінологічним словником, є суттєвою опорою у формуванні необхідних комунікативних компетенцій. Вчені, які володіють комунікативною компетентністю знання, мають набагато ширшу компетентність, ніж це передбачає лінгвістична. У комунікативної компетенції, вважає Р. Хадсон, важливо не просто посилатися тільки на знання лінгвістичних форм, а, крім цього, включати також суть наукові знання, і в такому випадку, більш доречний термін «здатність» використання мовних форм (Hymes, 1972). Д. Каплан (Caplan, 1987) доповнює таке розуміння, вважаючи, що деякі мовні структури, особливо деякі синтаксичні структури, i ментальні процеси, які їх реалізують, дуже специфічні і сильно відрізняються від будь-яких раніше описаних немовних розумових дій людей. 3 цієї причини вони повинні вважатися унікальними і автономними.

А. Кутлер, В. Клейн та С. Левінсон (Cutler, Klein \& Levinson, 2005) стверджують, що дослідник не повинен бути або тільки психологом, або тільки лінгвістом рівною мірою. I далі уточнюють: учений може бути, перш за все, психологом, але таким, який вивчає лінгвістичне поведінку, або лінгвістом, але таким, який використовує психологічні методи, що дозволяють досліджувати лінгвістичне поведінку. Найчастіше трапляється небажання психолінгвістівпсихологів заглиблюватися в теоретико-мовознавчі нюанси, а з боку психолінгвістівмовознавців відсутність віри в точність психологічних методів. Таким чином, основна ідея інтерпретації наукових фактів і їх взаємних імплікацій, тобто фактично об'єктом досліджень, є прагнення знайти всередині нової, повної і, в той же час, відкритої системи, неперервно виникаючих знань, мультидисциплінарну спільність, що $\epsilon$ логічною формою вкладу в розвиток психолінгвістичної науки. Отже, широкий спектр отриманих знань шляхом психолингвистических досліджень ніколи б не виник внутрі власне лінгвістики, будучи тільки психологічним. Разом 3 тим, психолінгвістичні підходи збагачують знання про мову, але, що не менш важливо, розширюють знання і про когнітивні процеси людини.

\section{Висновки \\ Conclusions}

Звернення до інтегрального поняття психолінгвістичного дискурсу дозволяє цілісно охопити основні аспекти проблеми мультидисциплінарного взаємодії в розвитку сучасних наукових теоріях. У психолінгвістиці, як розділі психології, який вивчає мову і мовлення, для емпіричного аналізу вибирається логічна, лінгвістична модель мови, яка враховує з психологічної точки зору психологічні процеси 
сприйняття, розумового перетворення і створення мовної інформації. Унікальність психолінгвістичного дискурсу полягає у тому, що теорії і моделі, які розвивалися на основі одного вчення систематично перевіряються 3 використанням методів, розроблених іншою наукою. Це динамічна і відкрита система нового знання, яке постійно розвивається.

Революційний вплив на розвиток мультидисциплінарних наукових досліджень, 3 використанням психологічного знання, надали прогресивні досягнення в мультідисциплінарних наукових дослідженнях, які об'єднані єдиним дослідницьким інтересом. Дискурсивний аналіз мультидисциплінарних досліджень передбачає спілкування між вченими різних наукових напрямків, i, отже, використання різних наукових мов. Звідси, виникає необхідність створення і впровадження уніфікованого єдиного простору нових знань, основними характеристиками яких $є$ досить динамічний розвитку, в тому числі завдяки рівню абстракції (моно, між- i мультидисциплінарної), що гарантує успішну методологічну рефлексію.

У методологічному сенсі, 3 цієї точки зору, сучасна психолінгвістика $є$ мультіціплінарной наукою і очолює піраміду наук мультидисциплінарного характеру.

\section{Література \\ References}

Caplan, D. (1987). Neurolinguistics and linguistic aphasiology. An introduction. Cambridge: Cambridge University Press.

Chomsky, N. (1965). Aspects of the Theory of Syntax. Cambridge, Massachusetts: MIT Press.

Cutler, A., Klein, W., \& Levinson, S. (2005). The Cornerstones of Twenty-First Century Psycholinguistics. In A. Cutler (Ed.), Twenty-first century psycholinguistics. Four cornerstones. Mahwah, NJ: Erlbaum.

Hymes, D.H. (1972). On Communicative Competence. In J.B. Pride, \& J. Holmes (Eds.), Sociolinguistics: Selected Readings (pp. 269-293). Harmondsworth: Penguin.

Weizsäcker, E., \& Wijkman A. (2018). Come on!: capitalism, short-termism, population and the destruction of the planet - a Report to the club of Rome. New York, NY: Springer Science+Business Media LLC. 